\title{
5' Exonuclease Apollo
}

National Cancer Institute

\section{Source}

National Cancer Institute. 5' Exonuclease Apollo. NCI Thesaurus. Code C91863.

5' exonuclease Apollo (532 aa, $\sim 60 \mathrm{kDa}$ ) is encoded by the human DCLRE1B gene. This protein is involved in both the repair of interstrand cross-links and telomere maintenance. 